CATALAN REVIEW

Catalan Review

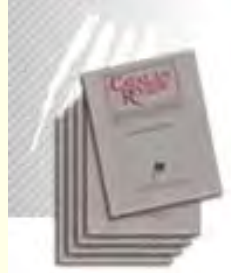

You are accessing the Digital Archive of the Catalan Review Journal.

By accessing and/or using this Digital Archive, you accept and agree to abide by the Terms and Conditions of Use available at http://www.nacs-

catalanstudies.org/catalan_review.html

Catalan Review is the premier international scholarly journal devoted to all aspects of Catalan culture. By Catalan culture is understood all manifestations of intellectual and artistic life produced in the Catalan language or in the geographical areas where Catalan is spoken. Catalan Review has been in publication since 1986 .
NORTH

AMERICAN

CATALAN

SOCIETY
Esteu accedint a l'Arxiu Digital del Catalan Review

A l' accedir i / o utilitzar aquest Arxiu Digital, vostè accepta i es compromet a complir els termes i condicions d'ús disponibles a http://www.nacs-

catalanstudies.org/catalan_review.html

Catalan Review és la primera revista internacional dedicada a tots els aspectes de la cultura catalana. Per la cultura catalana s'entén totes les manifestacions de la vida intel lectual i artística produïda en llengua catalana o en les zones geogràfiques on es parla català. Catalan Review es publica des de 1986.

\title{
The use of rhetorical figures in the poetry of Josep Carner Salvador Oliva
}

Catalan Review, Vol. VI, number 1-2 (1992), p. 371-391 


\section{THE USE OF RHETORICAL FIGURES \\ IN THE POETRY \\ OF JOSEP CARNER}

\section{SALVADOR OLIVA}

Only after the first real valuation of the poetry of Josep Carner, begun by Joan Ferraté and Gabriel Ferrater in the nineteen sixties, did a change come about in the consideration of Carner's poetry. The dominant opinion of Catalan literary criticism, which considered Carner a flowery poet and a versifier of the whims of philistines was gradually eliminated.

The difficulties of the readers who saw the publication of Poesia in 1957 to properly evaluate the revision and re-ordering of his later poetry, was partly due to the aesthetic preferences of the so-called social realism, which thought little of both the fixed forms and the imaginative distance from literal to figurative meaning. Neither did the consideration of Carner as a poet belonging to noucentisme help his work to be evaluated properly, because this movement was seen basically as a reflection of a conservative society. In recent years, Carner has been considered less and less as a poet belonging to the noucentisme, and indeed, the division between modernisme and noncentisme, with their traditionally established contrasts, will sooner or later have to be drastically revised.

The personal preferences of other critics, who saw in the poetry of Carles Riba, or even of J.V. Foix, a more genuine expression of modern taste, did not help either in the appreciation of Carner's greatness, for the appreciation of the first two meant the rejection of the classical aestheticism within which Carner was rooted from his very beginnings.

Another impediment to understanding Carner's poetry was the fact that the majority of young readers, who read 
Carner for the first time in the 1957 edition, found it difficult to appreciate an external form which Carner's imitators had worn out to an extreme. This had also happened with imitators of Riba-like López Picó-, and was to happen again with the poor imitators of Foix, who did the poet a grave disservice by imitating the most visible elements of his style.

Even now, there remain some difficulties in the ap-preciation of Carner's poetic works still to be dispelled. The first is the difficulty to see the values which lie hidden beneath its surface. One of the most constant characteristics of Carner's poetry is-as we will see below-the fact that his language often contains two parallel levels of meaning: the literal and the figurative, each of which functions separately and together. Many readers and even critics tend not to go any further than the literal one, which is the most superficial and easy to understand; whereas the underlying reading is much more complex, and sometimes contains a deliberately hidden meaning.

This fact is demonstrated by just those poems which only function with a symbolic meaning. This is the case of "Cor fidel», which we shall examine later. Very rarely, and perhaps never, have poems like these received critical attention.

The third difficulty, which is especially present for the Catalan reader, results from what we have said at the beginning: owing to the great, but in many cases superficial, success which the young Carner attained, the poets of his own generation (or those slightly younger) were very visibly influenced by him. Unfortunately, this influence did not go much further than what we might call superficial structures (part of his vocabulary and the exterior fixed forms: metre, rhyme, etc), and it provoked an avalanche of diluted flowery poetry, lacking in creative vigour. The mediocre quality of this verse was responsible for the insensitivity of many later readers of Carner, both those who during the Franco dictatorship would have preferred a kind of poetry which was 
more involved with the social reality of the country (because they must have been sincerely convinced that poetry could change the world), and also the ones who would have preferred a more symbolist poetry, nearer to the fashion of the time. The former must have found lacking the reflection of the social tensions of the country, and the latter the nervous jolt obtained by reading Riba and Valéry.

In order to illustrate these points we will look at a number of poems. The first, which is very simple and transparent, more than requiring two readings shows the advantage the reader receives if he pays a little attention to the rhetorical figures which appear in it, as these give the poem a deeper meaning.

This is the first poem of the last section of Poesia (1957), ABSĖNCIA, written in the poet's full maturity. In this poem, "De lluny estant", one of the main subjects of the book is dealt with: the experience of exile and the memory of one's native land, which Carner had not seen since that year.

Qui veiés, quan l'estiu s'acomiada, el cami-la serp blanca i somrient$i$, al marge d'una cala refiada, el pàmpol mort sota d'un pi vivent.

Qui veiés una dansa damunt l'era i una serra morada enllà de mi; qui topés un aloc de torrentera o enmig d'un pedruscall, un romani.

Més val, però, que a aquests bedolls s'acari el meu esment, i a aquest boiram somort. En mos camins d'un temps, hom pot trobar-hi un àngel trist $\mathrm{amb}$ el seu glavi tort. 
Who could see, when summer sais good-bye, / the path-that white and smiling snake- / and, next to a trusting cove, / the dead vine leaf under a living pine. // Who could see a dance in a farm-yard, / a purple mountain range far away from me; / who could come across a chaste tree near a gully / or, amidst the rubble, a rosemary bush. // But my thoughts had better face / these birches and this dim fog. / In my paths of yester-year can be found / a sad angel with a bent sword.

This poem is made up of a contrast between the native land (the first two stanzas), and that of exile (the first two lines of the third stanza), followed by a conclusion. The first stanza, which expresses the longing evoked by the Catalan countryside, contains certain rhetorical figures which give life to the content: all the elements which characterize the countryside function as synecdoches; the path, the cove, the vine leaf and the pine. The desire to see them expands to include seeing the whole country.

On top of these four identical figures, Carner constructs four more, which are also identical. Each one of these elements has a predicate which creates a pathetic fallacy; that is, which applies human qualities to natural elements. The summer says good-bye, the cove is trusting, the vine leaf is dead and the pine living. The path, then, instead of being accompanied by a predicate, has an apposition; it is compared, by means of a metaphor, to a snake, and in this case it is the predicate smiling applied to a snake which creates the pathetic fallacy.

In the second stanza, however, all the elements of the countryside that is called to mind, instead of being humanized by a predicate are placed in a spatial context: the dance takes place *damunt l'era» (in a farm-yard), the purple mountain range is "enllà de mi" (far away from me), the chaste tree is "prop d'un torrent" (near a gully), and the rosemary bush is «enmig d'una torrentera» (amidst a rubble). There are, therefore, eight synecdoches. Each of the four in the first 
stanza is accompanied by an example of pathetic fallacy to humanize the element of the landscape; whereas the four in the second stanza are each placed in a spatial context to bring about the same effect.

In the two first lines of the third stanza we find the main contrast: another country is called to mind, also by the use of two synecdoches: «bedolls" (birches) and «boiram» (fog). In the last two lines, the voice of the speaker tells us that, despite everything, his thoughts had better face up to the second landscape. Joined to the two previous lines by an implicit causal relation, the last two lines tell us that his preference is owing to the fact that in the land he misses, remembers and desires, there can be found the symbol of defeat: «un àngel trist amb el seu glavi tort» (a sad angel with a bent sword). Thus it is preferable not to satisfy a desire when we know that what is desired brings with it a deep sadness.

This poem, of an extremely simple conception, is a reflection made "de lluny estant» (from far away), as the title states. Although simple, however, it manages to achieve -apart from an extraordinarily vivid glimpse of the native countryside-by the rhetorical devices we have seen, an interesting moral reflection, because it avoids the reductionism into which many patriotic poems which deal with exile fall. Carner does not compare two countries in a Manichaean way, but rather two complex realities, with things both bad and good. And this value is not given conceptually, but by the use of the already mentioned rhetorical devices.

The main purpose of this poem-the first in the last section of Poesia - is extremely clear (as is always the case in the first and last poem of each section). Here it is to introduce one of the main subjects that recurs throughout all the last section.

The second poem we are going to examine, which is the fifth in the same section, is situated in a completely different 
tessitura from the first. Its external form is that of the sonnet. Neither does this poem, "Cor fidel", allow two readings-a literal one and an underlying one-because the poem itself cannot be reduced to the immediate meaning of its images.

\section{COR FIDEL}

A una dolor que va al dellà del seny fa només l'Impossible cara tendra.El pur palau esdevingué pedreny: els murs són aire, el teginat és cendra.

I, lladre d'aquest lloc desposseït, palpant, caient, a poc a poc alçant-se, el descoratjament roda en la nit, rapisser del record i la frișança.

Jo sê d'on ve l'inesgotable foc que animarà la morta polseguera.Veig l'últim monument en l'enderroc.

Jo pujaré, sense replans d'espera, cap al camí de l'alba fugissera pel tros d'escala que no mena enlloc.

\section{FAITHFUL HEART}

To a grief that goes beyond reason / only the impossible turns a gentle face. I The pure palace becomes a heap of stones, / its walls are air, its panels ash. // Marauder in that place of dispossession, / groping, stumbling, slowly straightening up, / discouragement roams the night, / plundering memory and desire. // I know from where the inexhaustible fire / will come to enliven the lifeless dust. / In those ruins I see the final monument. // I shall climb, with no resting-places, / up the path of the fleeting dawn / by what is left of the stair that leads nowhere.

The main subject of this sonnet is the kind of experience 
it describes: the collapse of the rational support of human life. Only what is impossible, what does not exist, is able to confront a pain that cannot be understood. It is, therefore, an experience of extreme pain, and the lines 4 to 8 explain the cause of it in terms which are understandable only at a symbolic level. The "pur palau" acts as a metaphor which has as a meaning the rationalizations we make from the immediate facts of our experience. (On this see Gabriel Ferrater's Prologue to Nabi, Barcelona 1991, Ed. 62, pages 7-8.)

In this metaphor, the word "palace» refers to an actual construction, while the adjective pure used to describe it, tells us that it is not a physical but mental or spiritual construction. The palace has been destroyed and reduced to a heap of stones. Where once there were walls, now there is only air, and fire has turned the panels into ash. Nothing of value, therefore, remains. There is only desolation and dispossession.

The sequence of negative experiences which life brings is precisely what destroys the rationalizations we make; that is, the constructions we create to explain what has happened to us, and to avoid the anguish of living a life without meaning. In other words, the rationalizations which can explain our past experiences to ourselves are inadequate to explain the new ones, and so they are destroyed like the palace of the poem.

The poem begins, then, precisely at the moment when a particular experience of intense suffering has gone about destroying the pure palace and converting it into rubble and ashes. In this scene of spiritual ruin, there is a sinister character. A thief plunders the place, where despite its destruction, there are still to be found two valuable things: memory and desire, which are two values which did not form part of the building. It is worth mentioning that in the Catalan version, «frisança (longing, fretting) is a metonymy for "desig» (desire). The seventh line tells us explicitly that this 
thief is discouragement. It is the feeling associated with the loss of the palace which makes the loss even greater, because it takes away the two consolations that remain and that are of value.

It is worthwhile mentioning that although the words acting as figures of speech do not make sense literally, they do, however, create a picture of a landscape consistent with destruction and isolation. Even in these symbolic poems, Carner never allows the vehicles of his metaphors to be incomprehensible as such, because they are not isolated, but joined together to create a compact meaning which in this case establishes a coherent vision with what we know of the physical reality. Nor is the figurative meaning less compact because it fashions a vision that is coherent with what we know of the life of the spirit.

The tercets show an attempt to escape from this situation of moral pain. Counterbalancing the fire which has destroyed the panelling, there is another inexhaustible fire, which is capable of putting life into the dust. Carner is a poet who completely rejects any kind of pessimism. In another poem in ABSÈNCIA, "A la immutable», speaking very figuratively for reasons of Franco censorship, he talks of abysses which will flower; abysses through which a channel of blood still passes. Despite Franco's destruction of Catalonia, Carner still believes that the country will flower. In a similar way in this poem, the destruction of the palace is not final, because the fire which will regenerate it is none other than that which a ecor fidel" (faithful heart) is capable of generating. The title is somewhat ambiguous. It may signify a heart with a religious faith, or a heart faithful to something. However it is not necessary to interpret this faith or fidelity in a sense of religious faith, or fidelity to a country which has been destroyed. The faithful heart may be that part of us which has to find sense amid the rubble. In the eleventh line the ruins are seen as a monument, which implies the trans- 
mutation of the prevailing values into social codes. That is, it is the ruins themselves which have the value of the monument, and not the pure palace which they were.

There is an ascending moral movement within the poem. This starts from a negative experience, which occupies the first two stanzas, but the power of the spirit emerges immediately to raise itself up once again and attain a situation which surpasses, in moral values, the previous situation of the destruction of the palace. As a result, the way out of the painful situation consists of climbing (also in a metaphorical sense) a ruined stairway which leads nowhere (at least to no visible place) in order to arrive at the path of the fleeting dawn. The dawn acts as a symbol for the constant new beginnings which make up all human lives.

It is not man who questions life, as some existential philosophers proposed, but vice versa: it is life which interrogates man, and the refusal to provide an answer to the questions life poses us at every event can only lead to an existence which is not authentic, an existence, therefore, which generates anxiety,

The poem is situated within a frame which presupposes that the questionings of life through which we have to pass are made up of different successive stages, and each new beginning (or growth) carries with it the pain of leaving what we had, in order to start again from nothing (On this point, we also refer the reader to "País perdut"). This is the meaning of the path of the fleeting dawn, or at least interpreted in this way, the poem is entirely coherent and full of meaning. The ruined stairs lead nowhere, but the effort to make sense out of the destruction of sense is the only attitude that can save us from believing what is not true; or rather it is the only possibility of avoiding being bogged down in constant grief. As a result, the fire of the ninth line can be understood as the inexhaustible force which lies in the depths of all human life. It is not a fire of destruction, but rather a spiritual force, a 
revitalizing spirit. Therefore the defeat is seen in a positive light, as a last monument. All that remains is to climb up the destroyed stairway, without ever stopping. We have said previously that this stairway does not refer to any visible place, nor to any part of the palace. In reality, if it leads anywhere, it is up the path of the fleeting dawn. This adjective makes us think that we must not understand this path as leading somewhere, but rather as a constant starting anew. In this sense this poem is related to "País perdut", as we have mentioned above. It is the constant adjustment to a search for meaning that is never static but always changing, which does not allow us to stop ("without resting-places»).

The third poem we shall look at also belongs to ABSÉnCIA. It is entitled «Confidència».

\section{CONFIDENCIA}

Tant sospirar, tant somniar!, i el dia, inútil, se me'n va.

Sóc un amic massa garlaire del pi, l'ocell i l'aire;

senyor tan sols, en un atzar passat de pressa, de borrissols i plomissols que un raig de sol travessa.

\section{CONFIDENCE}

So much sighing, so much dreaming / and the useless day escapes me. // I am too talkative a friend / of the pine, the bird and the air; // I am only lord, / in a chance quickly passed, / of fluff and down / pierced by a ray of sun. 
Here once again, nearly the entire poem functions with rhetorical figures or symbolic terms. The two verbs of the first line are metaphors which refer to the occupation of the lyrical poet. Sighing is related to the expressive function, and dreaming to the imaginative capacity. In the second line there is a synecdoche, day, for the sum of days which signifies time. Time escapes and is useless.

The next two lines corroborate the interpretation we have made of the two previous ones. The elements of nature: the pine, the bird and the air, also function as synecdoches. The one who speaks sees himself as a friend of nature who talks too much. This "too talkative" is connected with «useless" by the negative connotations both words have. Nor is the occupation of poet seen as something with meaning. Just at that moment, however, the poem changes direction, to consider more deeply this occupation which allows him to be lord of nothing (actually the fluff and down act metaphorically to designate verses, seen as things which have no value). This nothingness has the capacity of being il-lumi-nated, and thus filled with meaning.

The poem could perfectly well have been entitled "Art poèticas (Poetic art), for it contains a whole conception of poetry. Verses, in fact, are nothing, or rather they would be nothing, if they did not allow a ray of sun to pierce them. In the same way that a speck of dust, which is nothing, is illuminated by sunlight, verses also have the possibility of reflecting light; not sunlight, of course, but the light of truth which we see reflected in the verses of a poem. This truth is not an absolute and immutable one, but only the capacity to define the experience of the reader.

Very rarely can we see the power of a poem in the way that this "Confidència" shows us; a far cry from the pedantry of certain in symbolist poets. It shows a humble acceptance of the limits of literature; the knowledge of its poverty, but also of its riches. 
Another device used by Carner in his poetry is a rhetorical figure which owing to its lack of a specific name, I will call «the figure of the world upside down». It appears, among others, in two poems which we shall look at now: «Cel cobert" (Overcast sky), from OFRENA, and «Tarda d'estiu» (A summer afternoon) from LLUNARI.

\section{CEL COBERT}

El sol, enquimerat amb cada cosa, amagà tot avui șa festa d'or,

Sols perquè penso en vós, el dia mor entre una glassa de color de rosa.

\section{OVERCAST SKY}

The sun, annoyed with everything, / has hidden its golden feast all day. // Only because I think of you, the day dies / within a pink coloured gauze.

The pathetic fallacy returns here with the predicate «enquimerat» (worried to death). Because the sun has been worried, it has not let its feast of golden light be seen all day. However the fact that the one who speaks thinks of his loved one (the "vós» (you) to whom the poem is addressed) causes a pink colour to appear in the sky on the horizon, a witness of the presence of the sun. I have spoken of the figure of the world upside down. In fact, it is a kind of metonymy: taking the cause for the effect. It is the contemplation in solitude of a quite ordinary natural phenomenon which evokes the thought of the beloved, if only to wish that the loved one could share that vision. The red sunset, then, calls to mind the loved one; but the poem tells us this in reverse: it is the fact of thinking about her which provokes the red sunset. In 
this way, the poet gives a kind of cosmic power to the thoughts about love, which is capable of reminding the sun that it must show its power of being able to change the colour of the sky. In a more complex manner, we can see the same procedure in "Tarda d'estiu» (A summer afternoon).

\section{TARDA D'ESTIU}

Hi ha una dea en aquest cel de clara turquesa;

de la sesta allunya el tel; s'allarg amb peresa.

Ja ha minvat la xafogor i se sent un regueró com una sorpresa, i un ocell canta allí baix i el sol besa de biaix una rosa encesa.

Son espill la dea ha pres i s'hi mira, nua;

de son cos, en l'aire estès, un or lleu traspua.

Ja ha minvat la xafogor. Com invicte gonfanó son cabell desnua; del bes que ella ha somniat deixa el cel tot perfumat

la flonja corrua.

\section{I perquè l'adolescent} que mortal va néixer i sospira tot veient deserta una reixa, o llegeix, tímid, si pot, sota el crit del falciot que mai no se'n deixa. 


\author{
un moment sigui sortós, \\ pressentint les tremolors, \\ el goig i la queixa, \\ ella, aroma de son cos \\ va ventant desclosa, \\ pren aquell coixi de flors \\ on son cap reposa, \\ i el cinyell, que fa el desig, \\ $i$ aura fina, d'un trepig \\ com d'un que no gosa, \\ $i$ ho estufa com un vel \\ $i$ en $\mathrm{fa}$, sota el primer estel, \\ un gran núvol rosa.
}

\title{
A SUMMER AITERNOON
}

There is a goddess in this sky / of clear turquoise; / she moves away the afternoon haze, / and stretches out lazily. / The sultry heat has lessened, / and a brook is heard / as a surprise; / and a bird sings down there / and the sun's slanting rays / kiss a burning rose. // The goddess takes up her mirror, / and looks at herself, naked; / from her body a light gold breathes / into the wide air. / The sultry heat has lessened. / She undoes her hair, / an undefeated banner; / the soft coil leaves the sky / fragrant with the kisses / that she dreamt of. // And so the adolescent / who was born mortal, / sighs when he sees / a deserted window, / or reads, timidly, if he can, / under the swift's / unceasing cry. / For a moment he feels lucky, / foreseeing the trembling, / the delight and the moan; // suggestively, she fans the fragrance / of her body, / takes that cushion of flowers / on which her head rests, / and the girdle which incites desire, / and the faint breeze of a footstep / of one who does not dare; / and fluffs it out like a veil / making it, under the first star, / a big pink cloud.

The main theme of this poem is the amorous desire the adolescent feels for his beloved, who is not there. The deserted window grating reminds him of her, for in Carner's time it was common to see young people courting with a grating between them. In fact, the windows used to have window-seats set into the walls called *festejadors (courting 
seats). The absence of his loved one makes the adolescent, who is filled with desire, imagine a cloud he sees in the sky as a naked goddess.

The interesting fact of this poem is its internal movement. It invites us to see, from the first moment, the goddess who moves away the haze of the afternoon and stretches lazily, and who until the last moment we do not know is a cloud. The time of afternoon is emphasized by the lessening of the heat, the noise of the brook-also noticeable because the noise of the day has diminished-, the song of the swift and the inclination of the sun's rays. The second stanza explains the activities of the goddess; all with an erotic charge culminating in the kiss she has dreamed of, and which at the end we know is the kiss imagined by the adolescent as he gazes at the goddess in the sky. The entire third stanza is a subordinate clause of purpose which, at the same time as it characterizes the youth tells us the intention of the goddess. It contains the key which has stimulated the youth's imagination: having seen a window grating without his beloved on the other side. From then, the movements of the goddess are erotically charged, thinking of the youth, and they culminate in the formation of a big pink cloud.

In this way we are told indirectly that the goddess is a figment of the youth's imagination, as is her desire to please him. It is interesting to go over the narrative structure: the one who speaks imagines an adolescent, who imagines a goddess, who in turn imagines a kiss, and so on. The imaginative route, together with the rhetorical device of taking effect for cause gives the poem its strength.

Often the poetry of Carner dealt with subjects or stories which the typical readers of his day were reluctant to understand, because they were unable to imagine that he could invent anything which was not in accordance with the moral codes of society at that time. This is the case of his 
poems about prostitutes, which Carner decided to eliminate from Poesia; but it also the case of a poem entitled "Captivitat», which does appear in it. On examining this it can be seen how Carner took advantage of the subject to make an elliptical, but also understandable poem. We shall look at two poems from this section; the one just mentioned, and «Departiment».

\section{CAPTIVITAT}

Ets al parany, i pagues ta follia, tu que anaves dansant entre l'oreig; ni vagaràs en els camins del dia ni faran els teus braços bandereig.

Però, ton front, no cap recança el llaura, ton cos en cerca d'aire no s'esbat, ni mai no dreces com l'isard en caure, ulls plens d'una infinita llibertat.

Car la teva cintura en l'abraçada sembla llanguir de benaventurada; to boca riu, sota segells vermells,

i flors de garlanda t'han fet orba $i$ onsevulla que et giris et destorba l'escampall olorós dels teus cabells.

\section{CAPTIVITY}

You are trapped, and paying for your folly, / you who went dancing in the breeze; / neither will you wander through the paths of day / nor will your arms move aimlessly, // But your forehead will not be furrowed with longing, / your body does not thrash about in search of air, / you never raise, like the fallen deer, / eyes filled with an infinite freedom. // For in the embrace, your waist / seems to languish in bliss; / your mouth laughs, under red seals. // and the 
flowers of your garland have blinded you, / and whichever way you turn you are bothered / by the fragrant spreading of your hair.

This sonnet had already appeared as a previously unpublished poem in La inútil ofrena (1924), and was situated in the section OFRENA of Poesia. There is only one word which allows us to guess that this poem is addressed to a married woman, for the garland can be no other than the nuptial one. The title of the poem, "Captivitat", refers then to the captivity of marriage. The movement of the sonnet is made up of three parts. The first, which coincides with the first quatrain, refers to the situation. The girl has fallen into the trap and now must pay the consequences of her folly; precisely she who used to dance in the breeze (a metaphor to indicate her freedom in the past). The last two lines of the first stanza make reference to her future: from now on she will not wander down the paths offered by the day, nor will her arms be free.

The second part, coinciding with the second stanza, is made up of three adversative clauses which show surprise at the fact that the girl, in spite of being in a trap, shows no signs of sadness. Her forehead is not wrinkled with longing for something else; she does not, like fish out of water who cannot breathe, thrash about, nor are her eyes filled with an infinite desire for freedom like those of the deer when it has fallen into a trap.

This paradox is resolved in the third part, which consists of the last two stanzas of the sonnet. The reasons why she does not show the typical effects of captivity are the following: her waist (that is, her body, if we understand the expression as a synecdoche) within the embrace (that is, in the act of making love, if once again we understand the figure as a synecdoche) seems to languish with the happiness it feels. Under the lips of her husband, seen with the metaphor of seals (for his kisses represent the guarantee of his love), she 
(that is, her mouth, once again interpreted as a synecdoche to represent the whole) laughs. And she does so because the lips are the seals which guarantee his love. These facts mentioned in the first tercet are positive hindrances; they are advantages of her captivity, or in other words, they represent the positive side of her captivity which prevents her from seeing that she is a captive. In the last tercet we see other elements which also prevent her from realizing her captivity, but here they are elements which come from herself, and which also should be interpreted as synecdoches. In the first place there are the flowers of her nuptial garland, which besides being part of the ornament she wears, also symbolize all the happiness of the wedding. It must also be added that the nuptial garland of the bride was worn low on the forehead, and the flowers therefore actually restricted the wearer's vision. In this poem, then, the flowers literally hinder the girl's vision, but also act as a synecdoche for all the paraphernalia of the wedding. Anywhere the girl turns her head (an action which might allow her to see the trap) her vision is also disturbed by her hair, which is seen here as a fragrant spreading, and as a symbol of her erotic attraction.

We must be careful not to make this sonnet into a manifesto against marriage. The aim of poetry, like all art in general, is not to make general statements about anything. Here, the poem begins and ends with a particular situation, which requires our imaginative involvement. The interpretation each reader makes of this poem is his own responsibility, and is not that of the speaker of the poem, and even less of Carner, who is merely the maker of the verses. The value of the poem does not come from its vision of marriage as a captivity, but from the capacity of its words to evoke a particular situation to the reader, which can be used by him to enlarge his ethical imagination according to his own experience.

The last poem we shall look at here is "Departiment". 


\section{DEPARTIMENT}

La nostra amor hauria vist, sortada, per clarianes de recers obacs, el núvol rosa submergit als llacs, fermat el sol ponent dins la brancada.

I ja de tu me'n vaig, de ta abraçada i de tos ulls altívols i manyacs: és plena ma sendera de sotracs i hi ha, al darrera meu, la nuvolada.

Cruels amb si mateixos, els destins de la trama que ordiren fan esquinç: no em pren virtut ni saviesa em falca.

Sense esperó ni regna, el pensament, en una rauxa d'ombra i de lament, com en corser de condemnat cavalca.

\section{DEPARTURE}

If lucky, our love would have seen / through clearings in shady sheltered places $/$ the pink cloud submerged in the lakes, / the setting sun caught among the branches. // And I am leaving you, your embrace / and your haughty and loving eyes: / my path is filled with ruts / and betind me there are black clouds. // The fates, cruel with each other, / are tearing up the plot they wove: / neither virtue nor wisdom holds me up. // Without spurs or reins, thought / in a surge of darkness and lament, / rides like a charger of the damned.

Once again we are presented with an unbearable situation when love ends. The first stanza explains a picture of happiness depending on the condition «if our love had been lucky». Everything in this description is static: nothing is in movement. In fact, it seems as unreal as a picture postcard, depicting a sunset over a lake, where even the sun is tied up among the branches. Between the first and second stanza 
there is an "empty space", which suggests that this love was not possible. Immediately after that there is movement: the one who speaks is leaving her, the road he goes on is uneven, but what he left behind is still worse. The language is deliberately distorted. In Catalan one can only go away from a place, and not a person, so the use of the personal pronoun «yous is a substitution for a place, and the syour embrace» and "your eyes" also sound strange. Those eyes are "haughty" and "loving", two adjectives contradictory in meaning, that reveal something about the nature of the woman loved. Although the road he has to follow is difficult, there is no possibility of returning.

The poem goes on to seek an explanation for the departure. The speaker imagines the fates as being cruel with each other; the ones who wove the love see their work destroyed by others. Neither virtue nor wisdom can provide him any support. Finally, in the last stanza, we see the situation with which he is faced: riding a horse to damnation withour reins or spurs.

In the first section, we have looked at three poems belonging to ABSENCIA, the last part of Poesia, all of them unpublished until 1957. As we have already said, Carner's poetic art was expressed in terms very different from those used by other poets of his generation. Carner's humility ("Senyor tan sols [...] de borrissols i plomissols») was difficult to understand just because a great many readers and critics, who were influenced by the symbolist aesthetics, understood or implicitly considered a poet as vates, giving a sacred value to his work. Carner's objectives were considered excessively simple or even trivial. It was really a problem of diction. Carner's choice of words, and even his combination of them, was not in keeping with the taste of the time. It is not that Carner did not take into account the power of the poet to illuminate aspects of reality - this power has been mentioned 
in "Confidència" - but rather that his choice of diction did not coincide with that of the time his books were published.

The other two poems, "De lluny estant", unpublished until I957, and "Cor fidel", published in Paliers (1950), show that all during his life, Carner was faithful to this kind of poetic art, which was rooted in the classical tradition. His was a diction and a codification which demand a very different reading from that required by such poets as Valéry, Mallarmé, or even Riba.

The second part of this article attempts to demonstrate his use of metonymy to construct the inner form of several of his best poems. As we have seen, "Tarda d'estiu", which appeared in L'oreig entre les canyes (1920), and "Cel cobert", unpublished until 1957 , demonstrate two completely different uses of the same procedure: the interchange of cause and effect in order to intensify each of the two.

And finally, in the third part we have looked at two poems from OFRENA: "Captivitat" and "Departiment». The first, as we have already said, first appeared in La inutil of rena (1924), and the second in the journal La Veu de Catalunya, in 1925 . With these two sonnets from the same period, I have tried to demonstrate that Carner did not only detach himself from the aesthetics of his time, but also from the ethical codes of the same society. He had already done so in some poems from the Segon llibre de sonets (1907), and La paraula en el vent (I9I4). Carner was a poet great enough to be above the limits imposed by the moral and aesthetic standards of his time.

SALVADOR OLIVA UNIVERSITAT DE GIRONA

(Translated by Marguerite Hartland) 